\title{
Corrosion-Inhibitor Efficiency Control: Comparison by Means of Different Portable Corrosion Rate Meters
}

\author{
1. Martínez ${ }_{,}^{\neq \star}{ }^{\star}$ C. Andrade, ${ }^{\star}$ N. Rebolledo, ${ }^{*}$ L. Luo, ${ }^{* \star}$ and G. De Schutter ${ }^{\star \star}$
}

\section{ABSTRACT}

Corrosion-inhibiting substances have been applied to suppress corrosion mainly on bare steel, but when corrosion is progressing. suppression can be achieved if anodic and cathodic reactions are avoided, which is not an easy objective, particularly if the bare metal is surrounded by concrete. In the present article, several corrosion inhibitors are studied to identify their inhibition efficiency in concrete. The percentage of reduction of the corrosion rate without and with inhibitor is named "inhibition efficiency." This definition calls for the measurement of the corrosion rate and makes its measurement a must when studying corrosion-inhibiting substances. The most extended technique used for the corrosion rate quantification is based on the calculation of the polarization resistance, $R_{p}$. For the study presented in this article, several portable corrosion rate meters based on the $R_{p}$ technique have been used. These equipment are needed for the evaluation of large structures and are able to confine the current in small areas or to determine the steel area affected by the signal for a correct corrosion rate calculation. A comparison among the different corrosion rate meters used for the inhibitor's efficiency has been done. This comparison has indicated that the corrosion rate meter with nonefficient confinement of the current is not able to detect clearly the passivation state.

KEY WORDS: confinement, corrosion, inhibitors, polarization resistance, reinforcement

Submitted for publication April 2008; in revised form, October 2009.

* Corresponding author. E-mail: isabelms@ietcc.csic.es.

* Instituto Eduardo Torroja de Ciencias de la Construcción, Madrid, Spain.

** Magnel Laboratory for Concrete Research, Faculty of Engineering. Gent University, Belgium.

\section{INTRODUCTION}

Corrosion of steel reinforcement can be initiated when chlorides in enough quantity or the carbonation front reaches the bar surface. This corrosion is known to be the cause of structural damages, and its prevention or reduction is of primary importance. Several methods can be used to delay the onset or stop the development of corrosion. Among these, corrosion inhibitors are the method studied in the present work.

Corrosion inhibitors can be added during the mixing of concrete, or as made more recently, can be applied on the concrete surface/to penetrate through the concrete pores and reach the bar surface. ${ }^{1}$ Both situations require different conditions.

When added in the mixture to prevent carbonation-induced corrosion, the amount of an inhibitor can be calculated as a function of the concrete mixture proportions; however, for the case of chloride-induced corrosion, the added amount of inhibitor would depend on the maximum chloride expected to reach the bar surface. This is not easy to be predicted, and therefore, the concrete properties with the inhibitor and other admixtures used need to meet the design specifications for workability, strength, and concrete durability.

Regarding inhibitors to be applied in existing corroding structures, the amount to be applied is still under discussion because the efficiency of these inhibitors has not yet been proven. ${ }^{2}$ For being effective, these surface-applied inhibitors should penetrate with whatever mechanism throughout the concrete pores, reach the bar surface, penetrate the oxides 
layer, and stop the corrosion/dissolution of the steel. This process has not been demonstrated to occur effectively in concrete yet. ${ }^{3}$

Corrosion-inhibiting substances have been applied to suppress corrosion mainly on bare steel, but when corrosion is progressing, its suppression is necessary for the inhibiting substance, either to avoid anodic or cathodic reactions, which is not an easy objective, particularly if the bare metal is surrounded by concrete.

In any case, dealing with the study of different substances potentially having corrosion-inhibiting properties, it is necessary to define what is understood by "inhibiting efficiency" and how to account for it. In general, inhibition efficiency is accounted for through the following expression: ${ }^{4}$

$$
\begin{gathered}
\text { (\% inhibition efficiency) }= \\
\frac{I_{\text {corr }} \text { without inhibitor }-I_{\text {corr }} \text { with inhibitor }}{I_{\text {corr }} \text { without inhibitor }} \times 100
\end{gathered}
$$

That is, the percentage of reduction of the corrosion rate without and with inhibitor is named "inhibition efficiency." This definition calls for the measurement of the corrosion rate and makes its measurement a must when studying corrosion-inhibiting substances.

Corrosion rate can be measured by means of different techniques: gravimetry, extrapolation of Tafel region of polarization curves, or the polarization resistance method, $R_{p} .{ }^{5}$ The last one is the only technique able to monitor the corrosion rate in a non-destructive manner in concrete. ${ }^{6}$

It has to be mentioned that other techniques, such as the measurement of the corrosion potential, cannot give reliable information due to its qualitative nature. A shift in the potential due to the addition of an inhibitor in itself, whether this shift is toward cathodic or anodic directions, cannot be conclusive; therefore, corrosion potential measurement is a complement and not a conclusive technique for measuring the inhibiting efficiency.

In the present article, several corrosion inhibitors are studied to identify their inhibiting efficiency in concrete. For the study, several portable corrosion rate meters have been used. The use of portable devices appears necessary because of the size of the testing slabs with relatively long rebars, which calls for the use of equipment able to confine the current in small areas to get the local, and not an average, value of the corrosion rate.

There are very few commercially available portable corrosion rate meters for measuring in large concrete structures. ${ }^{7-8}$ This is due to the need to use techniques to calculate the area polarized during the measurement efficiently. ${ }^{9}$ The most used technique is the so-called "modulated confinement of the current," 10 which'uses, surrounding the central auxiliary electrode, a second electrode as a "guard ring."
TABLE 1

CNI Protection Table for $\mathrm{Cl}^{-}$Concentrations ${ }^{17}$

\begin{tabular}{ccc}
\hline $\begin{array}{c}\mathrm{CNI} \\
\left(\mathrm{L} / \mathrm{m}^{3}\right)\end{array}$ & $\begin{array}{c}\text { Maximum } \\
\left(\mathrm{kg} / \mathrm{m}^{3}\right)\end{array}$ & $\mathrm{Cl}^{-} / \mathrm{NO}_{2}^{-}$ \\
\hline 10 & 3.6 & 1.3 \\
15 & 5.9 & 1.5 \\
20 & 7.7 & 1.4 \\
25 & 8.9 & 1.3 \\
30 & 9.5 & 1.2 \\
\hline
\end{tabular}

The current passing through this guard ring has to be modulated according to the current applied from the central counter electrode to maintain the correct confinement during the whole time of duration of each measurement. The "modulated confinement of the current" technique has been calibrated using gravimetric tests, ${ }^{11}$ and recent studies have proven good repeatability and reproducibility of the results. ${ }^{12}$

In the present study, Ghent University has developed an extensive study on the efficiency of several inhibitors using one of the corrosion rate meters available on the market, ${ }^{13}$ but because some of the results obtained where contradictory, they tried to measure with other equipment to rule out whether it is a matter of the equipment or if the effect can be attributed to the inhibitors themselves.

\section{EXPERIMENTAL PROCEDURES}

\section{Inhibitors Used}

Two different inhibitors were tested:

Calcium Nitrite (CNI) - Calcium nitrite is the most commonly used corrosion inhibitor and has been studied extensively for a long time. Its application on reinforced concrete has been studied for more than two decades, ${ }^{14}$ but as CNI acts as a moderate accelerator on hardening concrete, it normally requires the addition of a water reducer and retarder in the concrete mixture. It is identified as an anodic corrosion inhibitor. The mechanism of action has been studied by different authors. ${ }^{15}$

Most of the corrosion studies have shown a critical concentration ratio between nitrite and chloride, although the values differ depending on the type of concrete used. In general, a $\mathrm{Cl}^{-} / \mathrm{NO}_{2}^{-}$ratio (in molar) from 0.8 to 1.5 is required for complete protection. ${ }^{16-17}$ In a previous work, ${ }^{17}$ a table recommending the dosage of inhibitors depending on the chloride concentration in the concrete is provided. It is summarized in Table 1.

Aqueous Mixture of Amine and Ester (OCI) Organic corrosion inhibitors have been studied and used in reinforcement recently. The components and working principles of organic corrosion inhibitors seem to be far more complicated than those of CNI. In general, the effective components of organic corrosion inhibitors are alkaloamines, amine alcohols, and fatty 
TABLE 2

Nomination and Description of the Test Groups

\begin{tabular}{ccccccc}
\hline Name & Details & Name & Details & Name & Details & Name \\
\hline 500 & REF $+0 \% \mathrm{Cl}$ & 501 & $\mathrm{OCl}+0 \% \mathrm{Cl}$ & 503 & $\mathrm{CNI} 15+0 \% \mathrm{Cl}$ & 512 \\
510 & $\mathrm{REF}+1 \% \mathrm{Cl}$ & 511 & $\mathrm{OCl}+1 \% \mathrm{Cl}$ & 513 & $\mathrm{CNI} 15+1 \%+1 \% \mathrm{Cl}$ & 514 \\
520 & $\mathrm{REF}+2 \% \mathrm{Cl}$ & 521 & $\mathrm{OCl}+2 \% \mathrm{Cl}$ & 523 & $\mathrm{CNI} 15+2 \% \mathrm{Cl}$ & \\
\hline
\end{tabular}

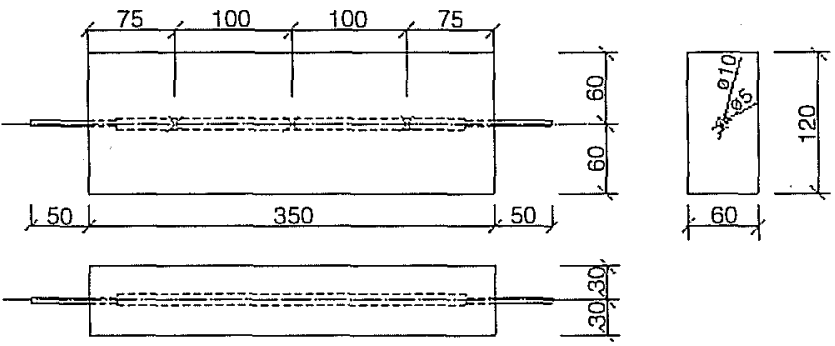

FIGURE 1. Dimensions of the reinforced specimens (unit: $\mathrm{mm}$ ) (" $\mathrm{x}^{u}$ represents the locations for corrosion measurement).

acid esters. ${ }^{18-19}$ Commercially available organic corrosion inhibitors may be a blending of several effective organic components and some inorganic salts.

In this study, a commercially available organic corrosion inhibitor, OCI, has been studied. According to the producer, this corrosion inhibitor comprises an aqueous emulsion of esters and amino alcohols. It affects corrosion through a combination of active and passive mechanisms. Previous studies ${ }^{20}$ have evaluated the effectiveness of OCI in inhibiting reinforcement corrosion, particularly when chloride or sulfate ions are built in the concrete. It was found than OCI can effectively delay the initiation of reinforcement corrosion.

\section{Materials and Specimens}

The specimens used for the comparison were:

Small Beams ( 350 by $120 \mathrm{~mm}$ ) - The beams were cast with chlorides mixed in the water, and, in some cases, corrosion inhibitors also were included. Portland cement CEM I $52.5 \mathrm{~N}$ was used in the concrete mixture. The reinforced concrete specimens were cast. with a water cement ratio $(\mathrm{w} / \mathrm{c})$ of 0.55 and a cement content of $300 \mathrm{~kg} / \mathrm{m}^{3}$. This $\mathrm{w} / \mathrm{c}$ ratio is quite high, and, in consequence, the high porosity in the concrete will speed up the ingress of chloride. The coarse aggregate content was $1,237 \mathrm{~kg} / \mathrm{m}^{3}$ and the sand content was $666 \mathrm{~kg} / \mathrm{m}^{3}$. The applied amount of the inhibitor named as OCI (aqueous mixture of amine and ester) ( $5 \mathrm{~L} / \mathrm{m}^{3}$ concrete) is suggested by the producer and is fixed for all exposure conditions. The amount of the inhibitor named CNI (calcium nitrite-based corrosion inhibitor with a minimum content of $30 \%$ of active ingredients by mass) was varied with chloride exposure conditions. Three dosages, namely $10 \mathrm{~L} / \mathrm{m}^{3}$, $15 \mathrm{~L} / \mathrm{m}^{3}$, and $20 \mathrm{~L} / \mathrm{m}^{3}$ by volume of concrete of CNI,

\footnotetext{
${ }^{\dagger}$ Trade name.
}

were applied. To evaluate the corrosion-inhibiting properties of the corrosion inhibitors under the internal chloride environment, in some groups $1 \%$ and $2 \%$ chloride (in the form of sodium chloride) by mass of cement was added in the concrete during casting, respectively. The description of each test group is shown in Table 2.

Each specimen has one carbon steel bar with a diameter of $10 \mathrm{~mm}$ embedded. The steel bars were first cut to a $300-\mathrm{mm}$ length. Then the two ends were connected mechanically with stainless steel bars with a diameter of $5 \mathrm{~mm}$ and length of $75 \mathrm{~mm}$. The goal is to prevent the carbon steel from corroding due to direct exposure to the chloride solution. The whole bars were polished with sand paper to get rid of the existing rust. The dimensions of the specimens are shown in Figure 1.

After casting, the concrete was demoulded after $24 \mathrm{~h}$ and stored in a curing room at $20^{\circ} \mathrm{C} \pm 2^{\circ} \mathrm{C}$ and at least $90 \% \mathrm{RH}$ until the age of 28 days. Then, the specimens were stored in a climate room at $20^{\circ} \mathrm{C} \pm 2{ }^{\circ} \mathrm{C}$ and $50 \% \sim 60 \% \mathrm{RH}$.

To accelerate corrosion, all specimens were divided into two groups; Group A and Group. B. They were immersed periodically in $5 \mathrm{wt} \%$ (Group A) or 10 wt\% (Group B) sodium chloride solution separately. The solution concentrations were controlled regularly. The acceleration procedure consists of immersing the specimens in solution for 3 days and drying them in the climate room condition for the rest of the week, i.e., 4 days.

For the comparison among corrosion rate meters, not all the specimens described in Table 2 were used. Instead, eight representative slabs with different inhibitors and chloride contents were used, as indicated in Table 3.

Corrosion rate imeters used for its comparison in these slabs were Gecor $06^{\dagger}$ and Gecor $08^{\dagger}$, applying modulated confinement of the current, and Galvapulse $^{\dagger}$, applying non-modulated confinement of the current (Figure 2).

Large-Dimension Elements - These elements were not fabricated for this experimentation. They were reinforcement pieces cast without chlorides in the mixture some years before starting the tests. They have reinforcement in the passive state, and so, they were used for checking passive conditions. As has been mentioned, both of them were not contaminated with chlorides or other depassivating agents, so, very low corrosion rate values with high concrete resistivi- 
ties are expected. They have neither of the inhibitors in the mix. Two different elements were used:

-slab without chlorides $(1,500 \mathrm{~mm}$ by $1,500 \mathrm{~mm}$ approximately)

- column without chlorides $(300 \mathrm{~mm}$ by $1,500 \mathrm{~mm}$ approximately)

The equipment used for comparison in these slabs were Gecor 06 (applying modulated confinement of the current) and Galvapulse (applying non-modulated confinement of the current). Instead of using Gecor 08 with the same confinement system as that in Gecor 06, the potential attenuation method, also implemented in Gecor 08, was used for the evaluation of the slab without chlorides (Figure 3).

\section{Measurement Methods Used in the Corrosion Rate Meters}

As mentioned, the equipment used for the comparison were as follows:

-Gecor 06 and Gecor 08

-Galvapulse

These equipment, though they all have a guard ring, measure the corrosion rate in a different manner. Thus:

-Gecor 06 (Figure 4[b]): ${ }^{10}$ It measures by applying a galvanostatic step (minimum $5 \mu \mathrm{A}$ ), lasting $30 \mathrm{~s}$ to $100 \mathrm{~s}$, from the central counter. This step can be higher depending on the first trial response. Then, another counter current is applied from the external ring, and this external current is adjusted by means of measurement of the electrical field between the two reference electrodes called "ring controllers" to equilibrate internal and external currents, as shown in Figure 5(a). Therefore, the current applied by the guard ring changes during the measurement depending on the potential measured between the two ring controllers. To ensure a good confinement, this potential measured between the two ring controllers must be near zero during the measurement, and the device varies the

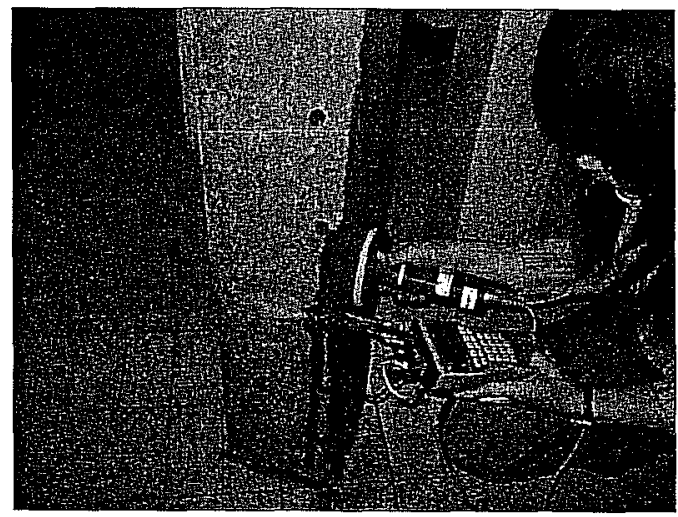

(a)
TABLE 3

Description of the Specimens Used for the Corrosion Rate Meter Comparison

\begin{tabular}{lcccc}
\hline Name & $\begin{array}{c}\text { Inhibitor } \\
\text { Type }\end{array}$ & $\begin{array}{c}\text { Quantity } \\
\left(1 /{ }^{3} \text { Concrete }\right)\end{array}$ & $\begin{array}{c}\% \mathrm{Cl}^{-} \\
\text {in the } \\
\text { Mixture }\end{array}$ & $\begin{array}{c}\% \mathrm{Cl}^{-} \\
\text {in the } \\
\text { Immersed } \\
\text { Water } \\
\text { Solution }\end{array}$ \\
\hline $521-\mathrm{B} 1$ & OCl & 5 & 2 & 10 \\
$521-\mathrm{A} 1$ & OCl & 5 & 2 & 5 \\
$520-\mathrm{A1}$ & - & - & 2 & 5 \\
$500-\mathrm{A}$ & - & - & - & 5 \\
$514-\mathrm{B} 1$ & $\mathrm{CNI}$ & 20 & 1 & 10 \\
$514-\mathrm{A} 1$ & $\mathrm{CNI}$ & 20 & 1 & 5 \\
$512-\mathrm{A1}$ & $\mathrm{CNI}$ & 10 & 1 & 5 \\
$523-\mathrm{A1}$ & $\mathrm{CNI}$ & 15 & 2 & 5 \\
\hline
\end{tabular}

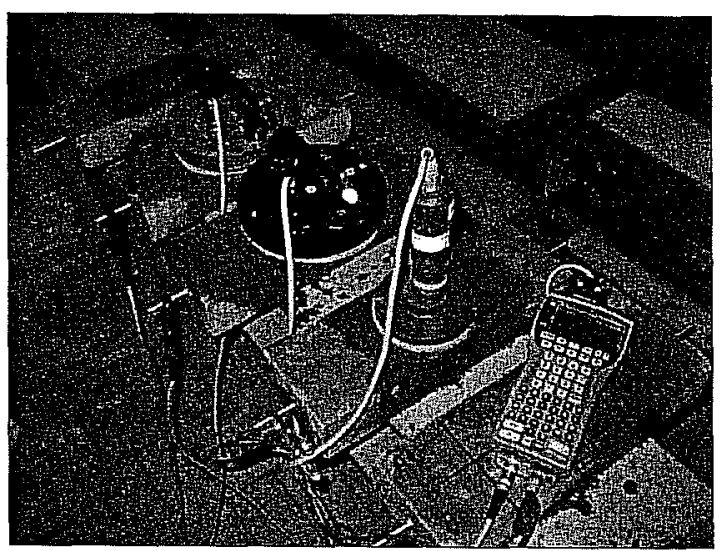

FIGURE 2. Gecor 06, Gecor 08, and Galvapulse sensors placed over the slabs.

current applied for the confinement to maintain this potential. ${ }^{21}$ This method is named "controlled confinement." The $\mathrm{R}_{\mathrm{p}}$ is calculated through the formula $R_{p}=\Delta E / \Delta I$ and the $I_{\text {corr }}$ through the Stern-Geary equation ${ }^{5} I_{\text {corr }}=B / R_{p}$, where $\mathrm{B}=26 \mathrm{mV}$. The area used for the calculation is that defined by a circle (Figure $5[\mathrm{~b}]$ )

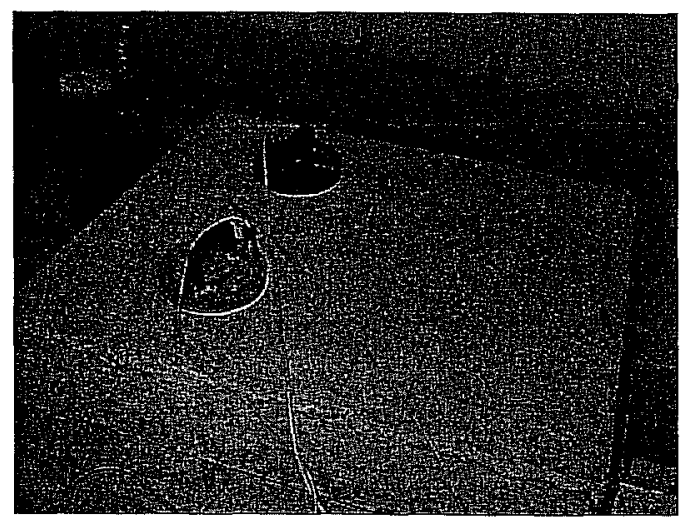

(b)

FIGURE 3. Large passive elements measured with Gecor 06, Gecor 08, and Galvapulse. 


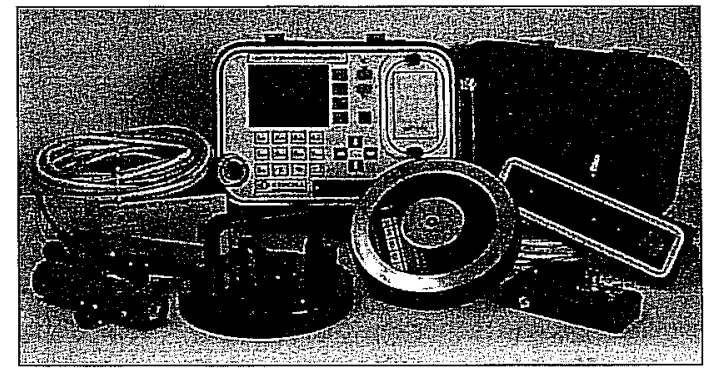

(a)

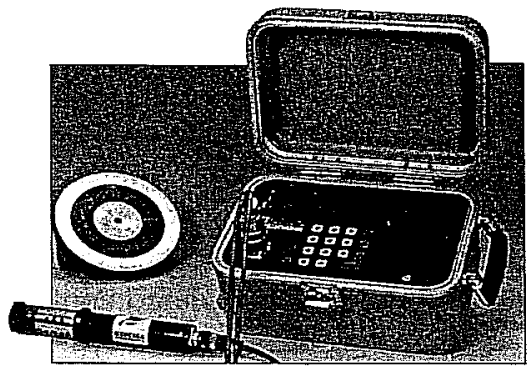

(b)

FIGURE 4. (a) Gecor 08 and (b) Gecor 06 devices.

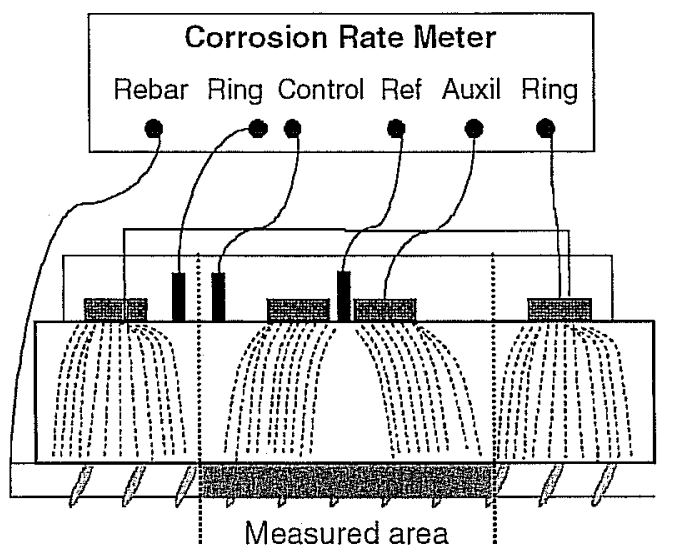

(a)

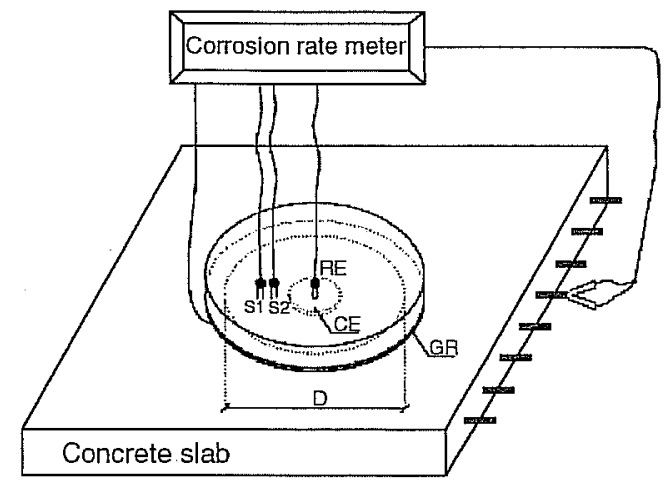

(b)

FIGURE 5. Modulated confinement system.

passing in between the two "ring controllers," where the diameter of this circle is $10.5 \mathrm{~cm}$. As has been mentioned before, the technique has been calibrated using gravimetry. ${ }^{11}$

-Gecor 08 (Figure 4[a]): This corrosion rate meter has several improvements with respect to Gecor 06. One improvement is the control of the guard ring confinement. Gecor 08 has a better confinement control that allows achieving quicker confinement. Apart from the modulated confinement method, Gecor 08 has another method of measuring $R_{p}$ based on the attenuation of the potential method. It is recommended when the concrete is very wet and its resistivity is so low that the confinement by the guard ring of the current cannot be well achieved. ${ }^{22}$ This method is based on the direct measurement of the "critical length." The sensor is formed, in this case, by a small disc acting as the only counter electrode that has in its center the reference electrode for the recording of $\mathrm{E}_{\text {corr }}$. Three other reference electrodes are placed aligned with the central reference at fixed distances (Figure 6[b]). For the measurement, a potentiostatic step, lasting between $20 \mathrm{~s}$ and $80 \mathrm{~s}$, is applied to the bar. This applied potential step attenuates with the distance, as observed in Figure 6(a). From the distance $\left(\mathrm{L}_{\mathrm{cri}}\right)$ reached by the signal and certain geometrical considerations of the bars' diameter, it is possible to calculate the $R_{p}$ with reference to a particular steel area.

—Galvapulse (Figure 7): ${ }^{7}$ This equipment applies, by a circular auxiliary electrode, a galvanostatic step of $5 \mu \mathrm{A}$ to $400 \mu \mathrm{A}$ during less than $1.0 \mathrm{~s}$. This current has to be selected by the operator because the equipment does not operate automatically. It calculates the $R_{p}$ from the ratio $(\Delta \mathrm{E}$ measured after less than $10 \mathrm{~s}$ )/(current applied). Simultaneously, the auxiliary guard ring applies a constant current that is not modulated during the measurement. The $I_{\text {corr }}$ value is calculated through the Stern-Geary equation taking $26 \mathrm{mV}$ as the $B$ value. The area used for the $I_{\text {corr }}$ calculation corresponds to the steel area located under the auxiliary guard ring, which has a diameter of $7 \mathrm{~cm}$. As in the previous devices, Galvapulse also has software for the $\mathrm{I}_{\text {corr }}$ calculation, but the user has to introduce the amount of steel that is under the measurement sensor.

Concerning the interpretation of the values of the corrosion current, Table 4 gives the ranges linked to the loss of steel cross section. ${ }^{23-24}$

Apart from the corrosion rate, the other electrochemical parameters related with the corrosion pro- 


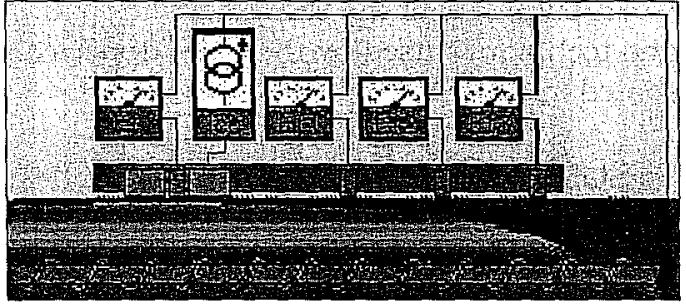

(a)

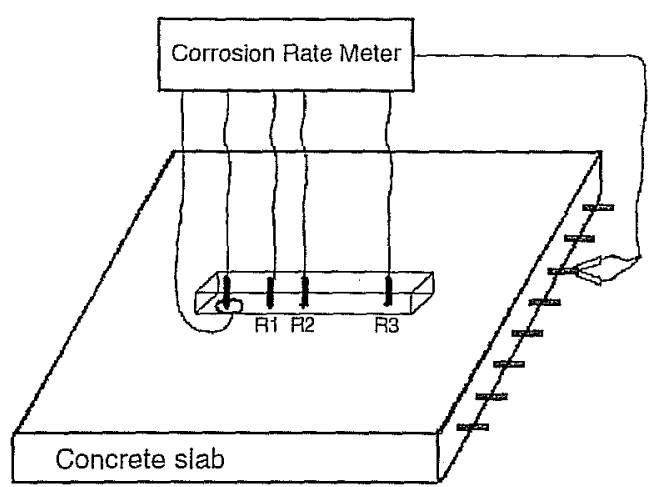

(b)

FIGURE 6. Potential attenuation method.

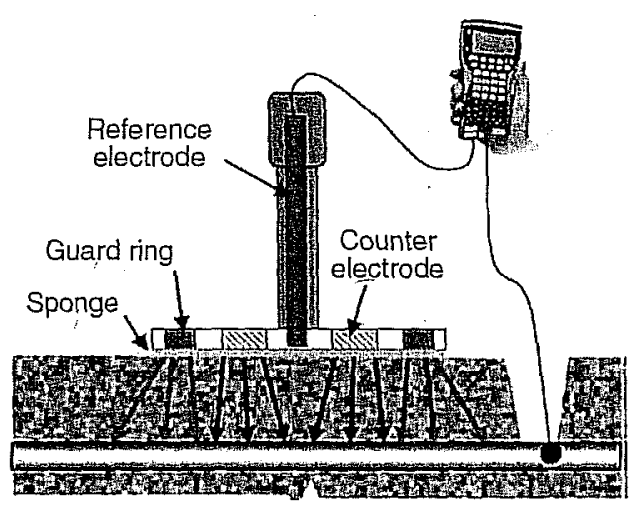

(a)

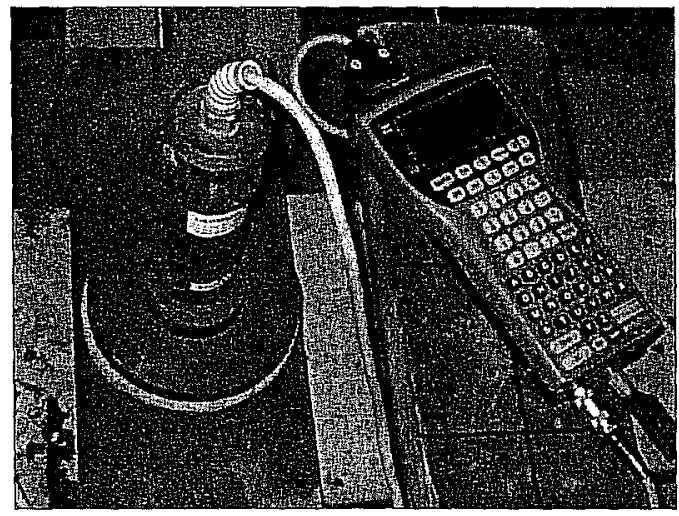

(b)

FIGURE 7. Galvapulse.

cess measured were half-cell potential, electrical resistance, and concrete resistivity.

The interpretation of the corrosion potential measurements, $\mathrm{E}_{\text {corr }}$ readings, has evolved during the last years. According to the ASTM C876 standard, ${ }^{25}$ a threshold potential value of $-350 \mathrm{mV}$ vs. copper/copper sulfate ( $\mathrm{Cu} / \mathrm{CuSO}_{4}$ ) electrode (CSE) was established. Lower values of potential suggested corrosion with $95 \%$ probability. If potentials are more positive than $-200 \mathrm{mV}_{\mathrm{cSE}}$, there is a probability greater than $90 \%$ that no reinforcement steel corrosion occurs, and for those potentials between $-200 \mathrm{mV}$ and $-350 \mathrm{mV}$, corrosion activity is uncertain. Copper/copper sulfate electrode is the most used electrode for in situ potential measurement, whereas calomel and silver chloride electrodes are used more in laboratory works. The potential difference between both electrodes depends on the temperature and the electrolyte concentration, but must be around $100 \mathrm{mV}$. (The difference with the standard hydrogen electrode [SHE] is $0.222 \mathrm{~V}$ for silver/silver chloride [Ag/AgCl], $0.1 \mathrm{M}$ potassium chloride [KCl], and $0.318 \mathrm{~V}$ for $\mathrm{Cu} / \mathrm{CuSO}_{4}$ sat.). During the comparison, the potential measurements were made with $\mathrm{Cu} / \mathrm{CuSO}_{4}$ electrodes (Gecor 06 and Gecor 08) and $\mathrm{Ag} / \mathrm{AgCl}$ electrodes (Galvapulse).
TABLE 4

Relation Between Corrosion Rate and Level of Corrosion

\begin{tabular}{ccc}
\hline $\begin{array}{c}\text { Corrosion Intensity } \\
I_{\text {corr }}\left(\mu \mathrm{A} / \mathrm{cm}^{2}\right)\end{array}$ & $\begin{array}{c}\text { Corrosion Rate } \\
I_{\text {corr }}(\mu \mathrm{m} / \mathrm{y})\end{array}$ & $\begin{array}{c}\text { Corrosion } \\
\text { Level }\end{array}$ \\
\hline$<0.1$ & $<1$ & Negligible \\
0.1 to 0.5 & 1 to 5 & Low \\
$0.5-1$ & 5 to 10 & Moderate \\
$>1$ & $>10$ & High \\
\hline
\end{tabular}

This electrical resistance, $R_{e}$, is the resistance due to the electrolyte. The devices to be used for on-site corrosion measurements have to be able to calculate the ohmic drop (IR) or to compensate it for its influence during the recording of the $\mathrm{R}_{\mathrm{p}}$ measurement. The $R_{e}$ is usually calculated from the potential step measured after the disconnection of the current in a galvanostatic pulse. Depending on the measurement time taken for the $R_{e}$ calculation and the magnitude of the pulse applied for the calculation, its value can vary depending on the type of equipment.

The resistivity of a given concrete is the electrical resistance standardized by the "cell geometry:" $R_{e}=$ $\rho \mathrm{A} / \mathrm{l}$ (where $\mathrm{A}$ is the cross-sectional area and $\mathrm{l}$ is the distance between electrodes). It provides information 


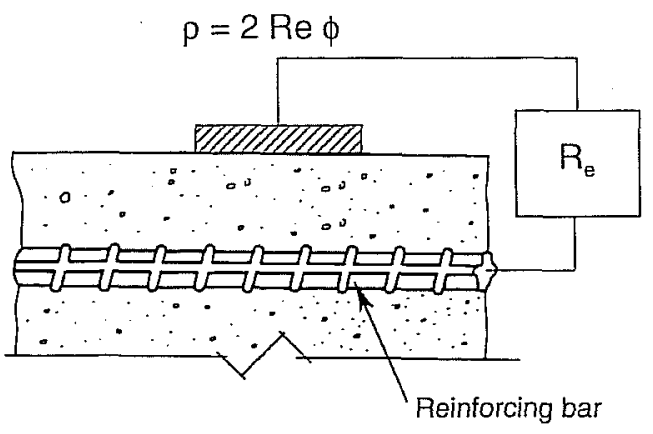

FIGURE 8. Disc method.

about the risk of early corrosion damage. A linear relationship between corrosion rate and electrolytic conductivity has been found experimentally; ${ }^{26}$ that is, low resistivity is correlated to high corrosion rate. If resistivity is higher than $100 \mathrm{~K} \Omega \cdot \mathrm{cm}$ to $200 \mathrm{~K} \Omega \cdot \mathrm{cm}$, there is no corrosion risk, but if resistivity is less than this threshold value, other parameters must be analyzed to determine the corrosion risk in the structure. The resistivity method that Gecor 06 and Gecor 08 have is the so-called "disc method." It is based on Newman's ${ }^{27}$ work and was fully developed by Feliu, et $\mathrm{al}^{28}$ (Figure 8). A galvanostatic pulse is applied, and then the ohmic drop is recorded from the instant response. The distance between the disk and rebar has to be at least two times the disk diameter. As shown in the upper part of Figure 8, the relationship between $\rho$ and $R_{e}$ is two times the diameter, $\phi$, of the disc electrode.

Resistivity and $\mathrm{E}_{\text {corr }}$ parameters can be interpreted jointly to give an index of corrosion risk. Even when the corrosion risk does not provide a quantitative corrosion measurement, it is very useful for a fast loca- tion of the most risky areas when measuring on site. The criteria given for obtaining the corrosion risk is indicated by a color (green, orange, or red if the risk is high, medium, or low, respectively).

A summary of the characteristics, parameters, and techniques used by the three devices are'presented in Table 5.

\section{RESULTS}

\section{Half-Cell Potential Measurement}

Half-cell potential measured in the beams made with the three instruments, as presented, are shown in Figure 9. Gecor 08 and Gecor 06 use a saturated $\mathrm{Cu} / \mathrm{CuSO}_{4}$ reference electrode, and Galvapulse uses a saturated $\mathrm{Ag} / \mathrm{AgCl}$ reference electrode. As was expected, more negative values are obtained with the $\mathrm{Cu} / \mathrm{CuSO}_{4}$ electrodes, which differs around $100 \mathrm{mV}$ from the $\mathrm{Ag} / \mathrm{AgCl}$ electrode. The differences between Gecor 08 and Gecor 06 are not significant except in two of the measurements (500-A and 514-A1). The measures show that specimens 514-A and 514-B, which have $20 \mathrm{~L} / \mathrm{m}^{3}$ of $\mathrm{CNI}$ inhibitor in their composition, are the only ones that provide corrosion potential less negative than the threshold of $-350 \mathrm{mV}$ for $\mathrm{Cu} /$ $\mathrm{CuSO}_{4}$ reference electrode and $250 \mathrm{mV}$ for $\mathrm{Ag} / \mathrm{AgCl}$, which indicates low corrosion risk. The other six specimens present corrosion potential values more negative than $-350 \mathrm{mV}$ for $\mathrm{Cu} / \mathrm{CuSO}_{4}$ reference electrode and $-250 \mathrm{mV}$ for $\mathrm{Ag} / \mathrm{AgCl}$, which indicates high corrosion risk.

Figure 10 shows the same parameter measured in the elements without chlorides (column and slab). Only Gecor 06 and Galvapulse were used for the measurements in these elements. In this case, all the

TABLE 5

Technical Differences in the Three Devices (for Corrosion Rate, Corrosion Potential, and Resistivity Measurements)

\begin{tabular}{|c|c|c|c|c|c|c|}
\hline \multirow[b]{2}{*}{ Method } & \multicolumn{3}{|c|}{ Gecor 08} & \multicolumn{2}{|c|}{ Gecor 06} & \multirow{2}{*}{$\begin{array}{c}\text { Galvapulse } \\
\mathrm{I}_{\text {corr: }}: \\
\text { non-modulated } \\
\text { confinement }\end{array}$} \\
\hline & $\begin{array}{c}\left.\right|_{\text {corr: }} \\
\text { attenuation } \\
\text { potential }\end{array}$ & $\begin{array}{c}\mathrm{I}_{\text {corr }}: \\
\text { modulated } \\
\text { confinement }\end{array}$ & $\begin{array}{l}\text { Corrosion risk } \\
\text { mapping }\end{array}$ & $\begin{array}{c}I_{\text {corr: }}: \\
\text { controlled } \\
\text { confinement }\end{array}$ & $\begin{array}{l}\text { Resistivity: } \\
\text { disc method }\end{array}$ & \\
\hline $\begin{array}{l}\text { Electrochemical } \\
\text { technique }\end{array}$ & $\begin{array}{l}\text { Potentiostatic } \\
\text { pulse }\end{array}$ & $\begin{array}{l}\text { Galvanostatic } \\
\text { pulse }\end{array}$ & $\begin{array}{l}\text { Galvanostatic } \\
\text { pulse }\end{array}$ & $\begin{array}{l}\text { Galvanostatic } \\
\text { pulse }\end{array}$ & $\begin{array}{c}\text { Galvanostatic } \\
\text { pulse }\end{array}$ & $\begin{array}{c}\text { Galvanostatic } \\
\text { pulse }\end{array}$ \\
\hline Pulse duration & $20 \mathrm{~s}$ to $80 \mathrm{~s}$ & $30 \mathrm{~s}$ to $100 \mathrm{~s}$ & $1 \mathrm{~s}$ to $2 \mathrm{~s}$ & $30 \mathrm{~s}$ to $100 \mathrm{~s}$ & $1 \mathrm{~s}$ to $2 \mathrm{~s}$ & $5 \mathrm{~s}$ to $10 \mathrm{~s}$ \\
\hline Pulse magnitude & $100 \mathrm{mV}$ & $5 \mu \mathrm{A}$ to $999 \mu \mathrm{A}$ & $5 \mu \mathrm{A}$ to $999 \mu \mathrm{A}$ & $5 \mu \mathrm{A}$ to $999 \mu \mathrm{A}$ & $5 \mu \mathrm{A}$ to $999 \mu \mathrm{A}$ & $5 \mu \mathrm{A}$ to $400 \mu \mathrm{A}$ \\
\hline $\begin{array}{l}\text { Pulse magnitude } \\
\text { selection }\end{array}$ & Automatic & Automatic & Automatic & Automatic & Automatic & Manual \\
\hline $\begin{array}{l}\text { Counter electrode } \\
\text { diameters }\end{array}$ & $20 \mathrm{~mm}$ & $\begin{array}{l}\text { Central: } 70 \mathrm{~mm} \\
\text { ring: } 180 \mathrm{~mm}\end{array}$ & $20 \mathrm{~mm}$ & $\begin{array}{l}\text { Central: } 70 \mathrm{~mm} \\
\text { ring: } 180 \mathrm{~mm}\end{array}$ & $20 \mathrm{~mm}$ & $\begin{array}{l}\text { Central: } 40 \mathrm{~mm} \\
\text { ring: } 70 \mathrm{~mm}\end{array}$ \\
\hline $\begin{array}{l}\text { Number of } \\
\text { electrodes }\end{array}$ & 4 ref, 1 counter & $\begin{array}{l}3 \text { ref, } 1 \text { counter, } \\
t \text { guard ring }\end{array}$ & 1 ref, 1 counter & $\begin{array}{l}3 \text { ref, } 1 \text { counter, } \\
1 \text { guard ring }\end{array}$ & 1 ref, 1 counter & $\begin{array}{l}1 \text { ref, } 1 \text { counter, } \\
1 \text { guard ring }\end{array}$ \\
\hline $\begin{array}{l}\text { Parameters } \\
\text { measured }\end{array}$ & $\mathrm{I}_{\text {corr }} \mathrm{E}_{\text {corr }} \rho, \mathrm{Re}$ & $I_{\text {carr }} E_{\text {corr }}, R e$ & $\begin{array}{l}E_{\text {carn }} \rho, \\
\text { corrosion risk }\end{array}$ & $E_{\text {corr }}, \mathrm{Re}$ & $\rho$ & $\mathrm{l}_{\text {corr }}, \mathrm{E}_{\text {corr }}, \mathrm{Re}$ \\
\hline
\end{tabular}




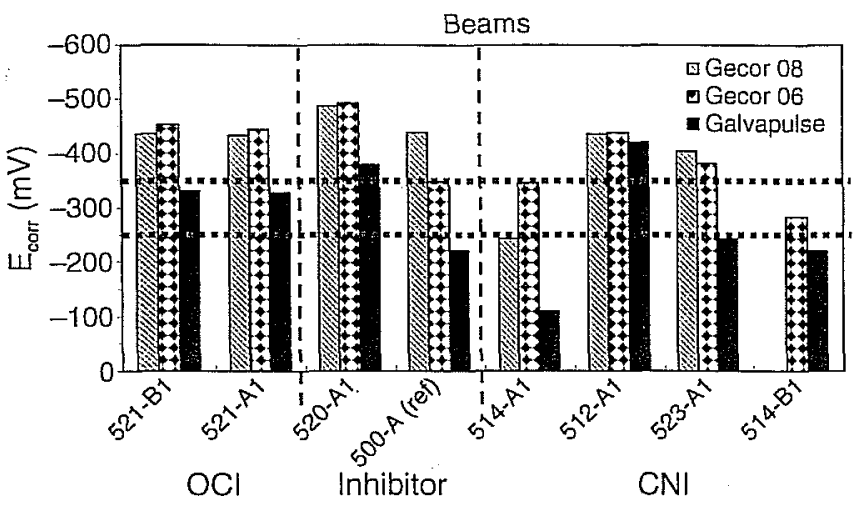

FIGURE 9. Half-cell potential measured in the beams with the three equipment.

values indicate low corrosion risk except the one measured in the column, which provides an $\mathrm{E}_{\text {corr }}$ value more negative.

\section{Electrical Resistance}

As discussed, the $R_{e}$ values are not useful for measuring inhibitor efficiency. They have been recorded just for noticing the IR drop that each equipment applies. In Figure 11, the values registered in the small beams are shown. Since they were in a submerged condition before starting the tests, resistances no higher than $2.5 \mathrm{~K} \Omega$ were registered. In all cases, Gecor 08 provides a higher $\mathrm{R}_{\mathrm{e}}$ result (between $1.2 \mathrm{~K} \Omega$ and $2.3 \mathrm{~K} \Omega$ ) than Galvapulse (between $0.6 \mathrm{~K} \Omega$ and $1.1 \mathrm{~K} \Omega$ ), whereas Gecor 06 provides lower results (between $0.3 \mathrm{~K} \Omega$ and $0.5 \mathrm{~K} \Omega$ ). Since the $\mathrm{R}_{\mathrm{c}}$ values are rather small, these differences are not significant.

In the specimens without inhibitors or chlorides, (larger elements) and in dry conditions (Figure 12), higher resistances are measured. In this case the Galvapulse device provides up to 4 times higher electrical resistances than Gecors.

\section{Concrete Resistivity}

Both Gecor 06 and Gecor 08 are able to measure resistivity using the "disc method" previously described. The Galvapulse device cannot perform this measurement, and thus, it was not possible to compare results with it. Table 6 shows the averaged values measured with a Gecor 08 device in the small beams and the slab studied.

Gecor 08 provides an indication of corrosion risk in addition to the information provided by corrosion potential and resistivity. Table 7 shows the corrosion risk indications provided by Gecor 08 using this "mapping method." Low corrosion risk (green indication) is noted; reinforcement should be in a passive state in the mapped area of the slab without chlorides.

\section{Corrosion Rate Measurements}

In the simall beams (with a 350-mm-length steel), Figure 13 shows results that seem to be similar to

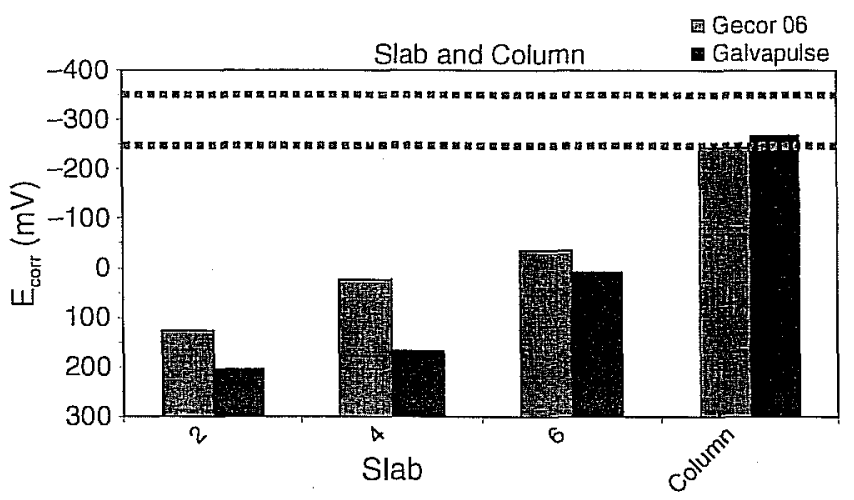

FIGURE 10. Half-cell potential measured in the elements without chlorides with Gecor 06 and Galvapulse.

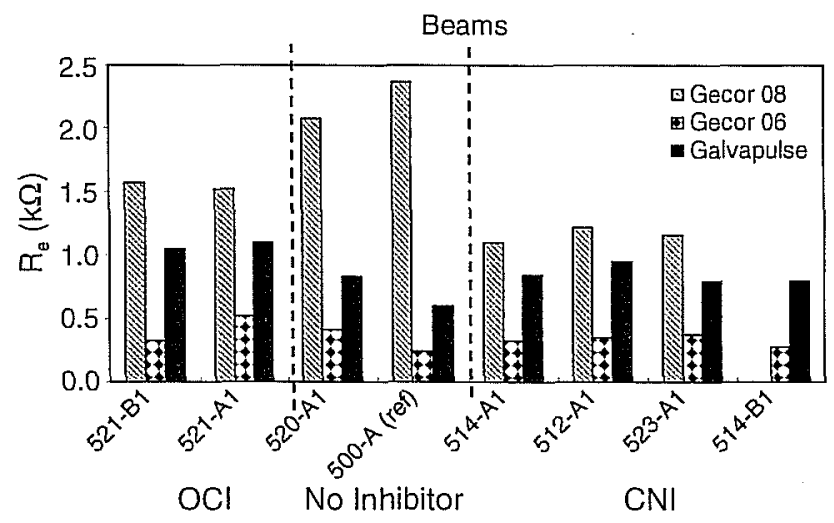

FIGURE 11. Electrical resistance measured in the beams with the three equipment.

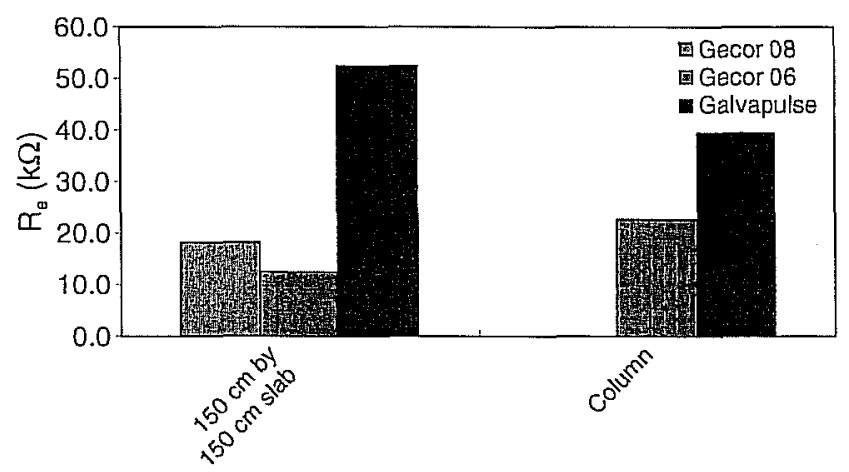

FIGURE 12. Electrical resistance measured in the elements without chlorides with Gecor 06 and Galvapulse.

those obtained with the three devices when measuring specimens with inhibitors 521-B1 (OCI), 521-A1 (OCI), 512-A1 (CNI), and 523-A1 (CNI). In these cases, the corrosion rate values are higher than $0.2 \mu \mathrm{A} / \mathrm{cm}^{2}$, which indicates that the corrosion process has not been suppressed by the OCI inhibitor or CNI at lower dosages. The three devices also provide similar results when measuring specimen 500-A (without chlorides and inhibitors in the mixture but immersed in a chloride solution) and 520-Al (with mixed chlorides but 
TABLE 6

Average Resistivity Values Measured with Gecor 08 Device in the Slabs and in the Beam

\begin{tabular}{ccc}
\hline & Small Beams & Slab \\
\hline Resistivity $(\mathrm{K} \Omega \cdot \mathrm{cm})$ & 4.99 & 198.3 \\
\hline
\end{tabular}

TABLE 7

Corrosion Potential, Resistivity, and Corrosion Risk Measured with Gecor 08 in the Slab Without Chlorides

\begin{tabular}{ccc}
\hline$E_{\text {cor }}(\mathrm{mV})$ & $\rho(\mathrm{K} \Omega \cdot \mathrm{cm})$ & Corrosion Risk \\
\hline-60.01 & 201.07 & Green \\
-137.47 & 104.8 & Green \\
-168.24 & 131.02 & Green \\
-179.36 & 175.52 & Green \\
-16.41 & 231.51 & Green \\
-32.79 & 137.22 & Green \\
-14.13 & 167.91 & Green \\
-24.16 & 176.23 & Green \\
-38.54 & 203.93 & Green \\
-10.67 & 210.67 & Green \\
-26.36 & 218.77 & Green \\
-10.79 & 337.4 & Green \\
-64.98 & 238.6 & Green \\
-54.58 & 179.86 & Green \\
-51.17 & 139.06 & Green \\
-10.62 & 319.36 & Green \\
\hline
\end{tabular}

without inhibitors). Both of them are also corroding. The main differences are found, however, in the small beams that seemed to be passive through the $\mathrm{E}_{\text {corr }}$ (Figure 9) (514-A1 and 514-B1), but now the Galvapulse device indicates much higher $I_{\text {сот }}$ results than those in Gecors. While the Gecors measure values much less than $0.1 \mu \mathrm{A} / \mathrm{cm}^{2}$, Galvapulse indicates values $\geq 0.2 \mu \mathrm{A} / \mathrm{cm}^{2}$. Galvapulse seems unable to detect the effect of the inhibitor in these specimens.

When the measurements are made in larger specimens (slab and column without chlorides or inhibitors), Galvapulse results are again much higher than Gecor 06 results (Figure 14). In these cases, Galvapulse gives corrosion rate values that nearly indicate active corrosion, although the steel bars are not corroding (Table 4).

In Figure 15, the results of the slab without chlorides are presented. The figure shows the comparison between Gecor 08 attenuation potential method and Galvapulse. Again, the results of Galvapulse are much higher, some indicating corrosion above $0.1 \mu \mathrm{A} / \mathrm{cm}^{2}$. In reality, the reinforcement remains passive, as Gecor 08 indicates.

\section{DISCUSSION}

\section{Inhibitors' Efficiency}

The results of the described experiments demonstrate a good efficiency of the inhibitor CNI when added in the mixture in the proportion of $20 \mathrm{~L} / \mathrm{m}^{3}$ of concrete and when the chloride concentration in the

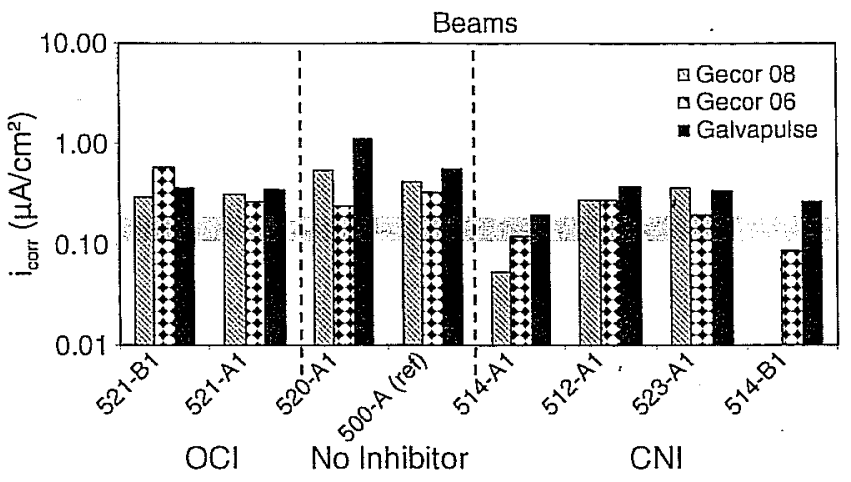

FIGURE 13. Corrosion rate measured in the beams with the three equipment.

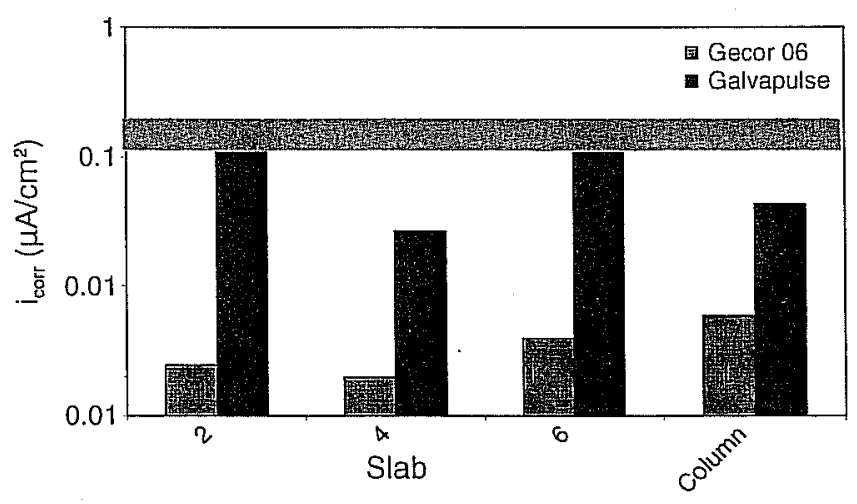

FIGURE 14. Corrosion rate measured in the slab and the column without chlorides with Gecor 06 and Galvapulse.

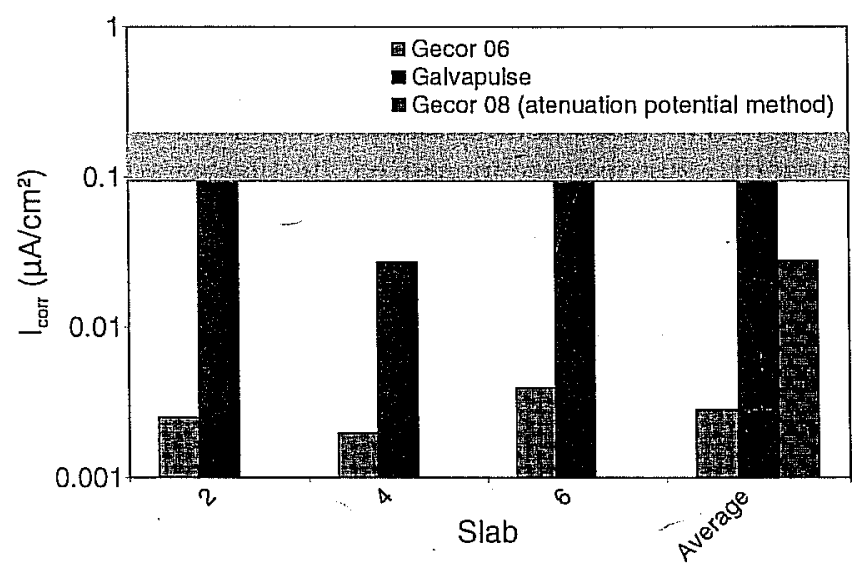

FIGURE 15. Corrosion rate measured in the slab without chlorides with Gecor 06, Galvapulse, and Gecor 08 (attenuation potential method).

mixture is $1 \%$, independently of the chloride water solution in which the specimens were immersed (10\% of chloride water solution for specimen 514-B1 and $5 \%$ of chloride water solution for specimen 514-A1). Corrosion rate values measured with Gecor 06 and Gecor 08 provided in the case of specimens 514-A1 (CNI) and 514-B1 (CNI) an average value of $0.088 \mu \mathrm{A} / \mathrm{cm}^{2}$ and $0.085 \mu \mathrm{A} / \mathrm{cm}^{2}$, respectively, which 
TABLE 8

Inhibitor Efficiency Calculation

\begin{tabular}{|c|c|c|c|c|c|c|}
\hline \multirow[b]{2}{*}{ Specimen } & \multirow[b]{2}{*}{ Inhibitor } & \multirow[b]{2}{*}{$\% \mathrm{Cl}^{-}$} & \multicolumn{2}{|c|}{$\mathrm{I}_{\mathrm{corr}}\left(\mu \mathrm{A} / \mathrm{cm}^{2}\right)$} & \multicolumn{2}{|c|}{$\%$ Inhibitor Efficiency } \\
\hline & & & Gecors & Gaivapuise & Gecors & Galvapulse \\
\hline $521-\mathrm{B} 1$ & $\mathrm{OCl}\left(5 \mathrm{~L} / \mathrm{m}^{3}\right)$ & $\begin{array}{l}2 \% \text { in the mix }+10 \% \text { in } \\
\text { the immersed solution }\end{array}$ & 0.51 & 0.36 & -27.50 & 67.27 \\
\hline $521-\mathrm{A1}$ & $\mathrm{OCl}\left(5 \mathrm{~L} / \mathrm{m}^{3}\right)$ & $\begin{array}{l}2 \% \text { in the } \mathrm{mix}+5 \% \text { in } \\
\text { the immersed solution }\end{array}$ & 0.29 & 0.35 & 27.50 & 68.18 \\
\hline $514-B 1$ & $\mathrm{CNI}\left(20 \mathrm{~L} / \mathrm{m}^{3}\right)$ & $\begin{array}{l}1 \% \text { in the } \operatorname{mix}+10 \% \text { in } \\
\text { the immersed solution }\end{array}$ & 0.085 & 0.27 & 78.75 & 75.45 \\
\hline 514-A1 & $\mathrm{CN} 1\left\langle 20 \mathrm{~L} / \mathrm{m}^{3}\right\rangle$ & $\begin{array}{l}1 \% \text { in the mix }+5 \% \text { in } \\
\text { the immersed solution }\end{array}$ & 0.088 & 0.19 & 78.00 & 82.73 \\
\hline $512-\mathrm{A} 1$ & $\mathrm{CNI}\left(10 \mathrm{~L} / \mathrm{m}^{3}\right)$ & $\begin{array}{l}1 \% \text { in the mix }+5 \% \text { in } \\
\text { the immersed solution }\end{array}$ & 0.27 & 0.36 & 32.50 & 67.27 \\
\hline 523-A1 & CNI $\left(15 \mathrm{~L} / \mathrm{m}^{3}\right)$ & $\begin{array}{l}2 \% \text { in the mix }+5 \% \text { in } \\
\text { the immersed solution }\end{array}$ & 0.28 & 0.34 & 30.00 & 69.09 \\
\hline 520-A1 & Reference & $\begin{array}{l}2 \% \text { in the mix }+5 \% \text { in } \\
\text { the immersed solution }\end{array}$ & 0.4 & 1.1 & & \\
\hline
\end{tabular}

correspond to a negligible corrosion rate following the criteria of Table 4 . The average corrosion rate value obtained with Galvapulse in these specimens is $0.19 \mu \mathrm{A} / \mathrm{cm}^{2}$ and $0.27 \mu \mathrm{A} / \mathrm{cm}^{2}$, respectively. Therefore, Galvapulse seems unable to detect the passive state and could fully mislead the conclusion if used alone.

When the $\mathrm{Cl}^{-} / \mathrm{NO}_{2}$ proportion increases, the efficiency of the inhibitor decreases, as shown in the specimen 523-AI $\left(15 \mathrm{~L} / \mathrm{m}^{3}\right.$ of $\mathrm{CNI}$ added with an admixture of chloride in the mix of $2 \%$ and immersed in $5 \%$ of chloride water solution) and in specimen $512-\mathrm{Al}\left(10 \mathrm{~L} / \mathrm{m}^{3}\right.$ of $\mathrm{CNI}$ added with an admixture of chloride in the mixture of $1 \%$ and immersed in $5 \%$ of chloride water solution). In these specimens, 523-A1 and 512-Al, the average corrosion rate values measured were $0.28 \mu \mathrm{A} / \mathrm{cm}^{2}$ and $0.27 \mu \mathrm{A} / \mathrm{cm}^{2}$, respectively, in the case of Gecors, and $0.34 \mu \mathrm{A} / \mathrm{cm}^{2}$ and $0.36 \mu \mathrm{A} / \mathrm{cm}^{2}$, respectively, in the case of Galvapulse. Therefore, in both specimens, Gecors and Galvapulse indicate corrosion levels higher than the steel depassivation threshold.

In the case of inhibitor OCI, the proportion of $5 \mathrm{~L} / \mathrm{m}^{3}$ recommended by the producer does not seem to be enough to suppress the corrosion process when $2 \%$ of chlorides are mixed in the concrete. The average corrosion rate values measured in specimens 521 $\mathrm{Bl}$ and 521-A1, which only differ in the chloride water solution in which they were immersed (10\% and 5\% of $\mathrm{Cl}^{-}$, respectively), are 0.51 and 0.29 , respectively, when measuring with Gecors, and 0.29 and 0.35 when measuring with Galvapulse. All these values are higher than the steel depassivation threshold.

\section{Calculation of Inhibitor Efficiency}

Regarding the inhibiting efficiency as defined in the Introduction and taking the values of $\mathrm{I}_{\text {corr }}$ calculated using controlled and modulated confinement by Gecors ahd non-modulated confinement by Galvapulse, Table 8 presents the inhibitor efficiency obtained in each case. The specimen taken as reference had $2 \%$ of chlorides in the mixture and was immersed in a $5 \%$ chloride solution. In this way, only specimens with inhibitors, and the same amount of chloride as that of the reference, are appropriate for the efficiency calculation. However, in Table 8, the calculation has been done for all the specimens, taking it as an approximation for the ones that are not in the same condition as that of the reference.

These results are misleading in certain perspectives, when considering only one device, because the higher the $\mathrm{I}_{\text {corr }}$, the higher the efficiency is if passivation values are reached with the inhibitor. However, when both devices are compared, it results in the contradiction that higher efficiency is indicated by the device giving the highest $\mathrm{I}_{\text {corr }}$ value.

\section{Corrosion Rate Measurements}

As has been shown, similar results are obtained with all the devices when small corroded slabs are evaluated. However, big differences are obtained when measuring with Gecor 06 and Galvapulse devices in passive reinforcements (Figure 13). These differences become much more important if the dimensions of the elements to be measured increase, as has been shown in Figure 14.

Other authors ${ }^{29}$ determined that Galvapulse in anodic areas is accurate and well within a factor of two for estimating the corrosion rate. In addition, the practical uncertainties when testing on site should be taken into account, e.g., the actual area of the reinforcement being polarized and the variation over time in corrosion rates related to temperature and moisture variations. In the same article, ${ }^{29}$ it was also mentioned that in passive reinforcement areas the Galvapulse will overestimate the corrosion rate by a factor of 3 to 4 times. Experimental results here, and other results published by other authors, ${ }^{30-31}$ show that the overestimation of Galvapulse in the corro- 

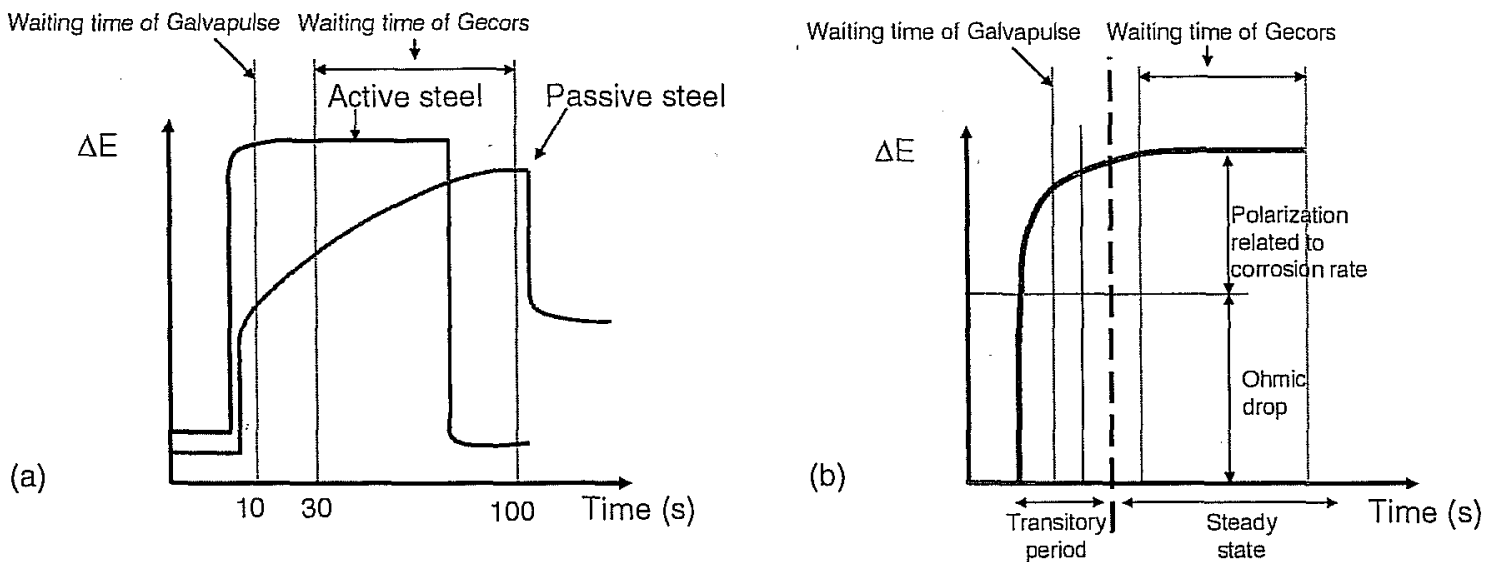

FIGURE 16. Galvanostatic pulse in active and passive conditions and waiting times used for the different devices for the lcorr calculation.

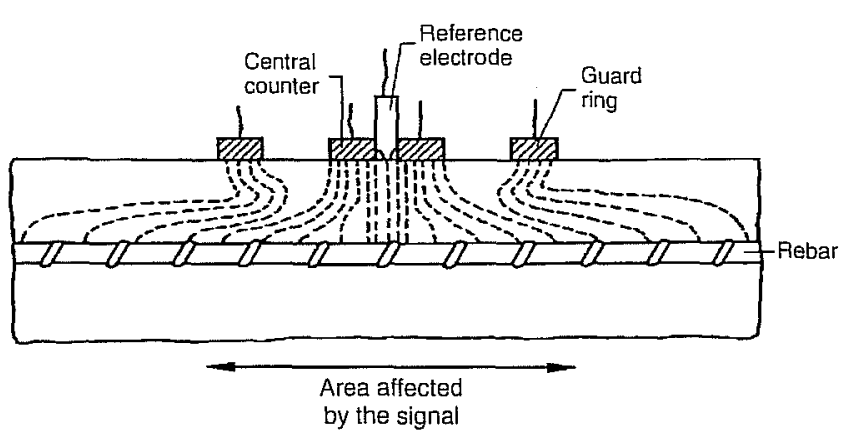

FIGURE 17. Incorrect modulated confinement of the current.

sion rate measurement is more than 3 to 4 times the values measured by the other devices, and there is no constant factor between the results provided by Galvapulse and those of the Gecors. However, what is more important is that Galvapulse seems never to measure values below $0.1 \mu \mathrm{A} / \mathrm{cm}^{2}$ (they were never registered in present tests), which makes it impossible to distinguish active corrosion from the passive condition of the steel. This circumstance makes it very difficult to measure the inhibitor efficiency with the Galvapulse equipment.

\section{Sources of the Differences Between Equipment}

For the differences detected between Galvapulse and Gecors, the explanation should be found in the measurement method used for the $\mathrm{I}_{\text {corr }}$ calculation. Even when Galvapulse and Gecors use galvanostatic pulses for the corrosion rate measurement, as has been commented on and shown in Table 5, two main differences exist in the confined galvanostatic pulse methods applied:

Polarization Time - For a correct corrosion rate measurement from the polarization resistance method, it has been demonstrated ${ }^{24.32}$ that there is a need to wait a certain time after application of the current or use a certain sweep rate to obtain a quasisteady-state value. In case of pulse measurements, this time changes depending on the type of pulse (galvanostatic or potentiostatic) and the corrosion state of the steel measured (when the steel is more corroded, less time is necessary to obtain the quasi-steady state). The Rilem recommendation on $R_{p}$ measurement ${ }^{24}$ proposes waiting times between $30 \mathrm{~s}$ (corroding) and $100 \mathrm{~s}$ (passive) in galvanostatic modes of operation (Figure 16[a]). Gecor devices never recommend polarization times shorter than $30 \mathrm{~s}$ to achieve a steady-state condition.

However, Galvapulse uses shorter times (less than $10 \mathrm{~s}$ ) for obtaining the steady state (Figure $16[b])$. As a consequence, the $R_{p}$ calculation from the expression $\Delta \mathrm{E} / \Delta \mathrm{I}$ provides $R_{\mathrm{p}}$ values smaller than the correct ones, and consequently, corrosion rate values obtained will be higher than the real or true ones.

Confinement System - Not all guarded techniques are efficient for the corrosion rate measurement on site. The only technique that is able to efficiently confine the current within a predetermined area (Figure 5) is the "modulated confinement" monitored by two small sensors of the guard ring control placed between the central auxiliary electrode and the ring. That implies a monitoring of the needed balance between the internal and external current applied. This is made by the smart software in the case of Gecor, while Galvapulse applies a constant external current with no modulation (no monitoring of the internal vs. external counter). In addition, with Galvapulse the current used for the internal and the external counters is the same and must be chosen by the user. The use of guard rings without correct control, as is the case shown in Figure 17, leads to too high values of the $I_{\text {corr }}$ for moderate and low values, and the error introduced in the case of very localized pits is very high. The larger specimen used for the tests more clearly shows the mistake in corrosion rate value. As explained previously, ${ }^{24}$ the error can be very high with non-modulated (nonmonitored balance) confinement of $I_{\text {corr }}$ determinations. 
When measuring on site it is necessary to account correctly for the polarized area. The delimitation of this area has to be made either by measuring the "critical length" (attenuation potential method) or by confining the current in a correct manner (modulated confinement). In addition, it is necessary to wait until a steady state is reached.

\section{CONCLUSIONS}

* The efficiency of the inhibitor used depends on the ratio $\mathrm{Cl}^{-}$/inhibitor. Only inhibitor CNI, when added in the mixture in the proportion of $20 \mathrm{~L} / \mathrm{m}^{3}$ of concrete with chloride concentration in the mixture of $1 \%$ (independently of the chloride water solution in which the specimens were immersed), was shown to reduce the corrosion rates significantly. Lower CNI inhibitor concentration or the use of OCI inhibitor has not shown enough corrosion-reducing efficiency.

* Care has to be taken when using the formula of \% of inhibition efficiency because the equipment give different $I_{\text {corr }}$ values.

* The type of corrosion rate meter used is crucial:

-In the case of corroding steel measured in small laboratory-sized specimens (steel bars no longer than $350 \mathrm{~mm}$ ), better correlations are obtained between Galvapulse and Gecor devices; however, when longer rebars are measured, larger differences between both confinement systems are detected. Since Galvapulse does not modulate the current through the counter electrode, the confinement does not seem to be fully achieved. The experimentally obtained conclusion is that the Galvapulse device generally considers a smaller area than the real polarized one, leading to an overestimation of the corrosion rate.

-In the case of non-corroding specimens, even when small laboratory specimens are measured, the Galvapulse device always gives higher values than those corresponding to passive steels. Therefore, Galvapulse does not seem to be able to detect the efficiency of corrosion inhibitors in concrete.

\section{ACKNOWLEDGMENTS}

The authors acknowledge the financial support from the Spanish Ministry of Education and Science under the CONSOLIDER SEDUREC of the program INGENIO 2010, as well as the support of the Special Research Fund of Ghent University, Belgium.

\section{REFERENCES}

1. B. Elsener, M. Buchler, F. Stalder, H. Böhni, Corrosion 55 (1999): p. $1,155-1,163$.
2. S. Qian, D. Cusson, Cem. Concr. Compos. 26, 3 (2004): p. 217-233.

3. B. Elsener, M. Buchler, F. Stalder, H. Böhni, Corrosion 56 (2000) p. 727.

4. C. Monticelli, A. Frignani. G. Trabanelli, Cem. Concr. Res. 30,4 (2000): p. 635-642.

5. M. Stern, A.J. Geary, J. Electrochem. Soc. 104, 1 (1957): p 56-63.

6. C. Andrade, J.A. Gonzālez, Werkst Korros. 29 (1957): p. 515.

7. B. Elsener, H. Wojtas, H. Böhni, “Galvanostatic Pulse Measurements-Rapid On-Site Corrosion Monitoring," Proc. Int. Conf. Corrosion and Corrosion Protection of Steel in Concrete, vol. 1 , held July 24-28 (Sheffield, U.K.: University of Sheffield, 1994), p. 236-246.

8. S. Feliū, J.A. Gonzälez, V. Feliū, S. Feliū, Jr., L. Escudero, I. Rodriguez-Maribona, V. Ausin, C. Andrade, J. Bolano, F. Jiménez "Method for Electrochemical Measuring the Corrosion Rate of Reinforced in Concrete Structures, Sensors and Device for Application of the Method," CA Patent no. CA2042883 (1991).

9. S. Feliú, J.A. González, C. Andrade, Corros. Eng. 51, 1 (1995): p. 79-86.

10. S. Feliū, J.A. Gonzãlez, S. Feliú, Jr., C. Andrade, Mater. J. ACI 9-10 (1990): p. 457-460.

11. C. Andrade, I. Martinez, Mater. Struct. 38, 11 (2005): p. 833-841.

12. I. Martinez, C. Andrade, N. Rebolledo, V. Bouteiller, E. MarieVictoire, G. Olivier, Corrosion 67, 2 (2008): p. 107-123.

13. L. Luo, "Influence of Corrosion Inhibitors on Concrete Properties. Microstructure, Transport Properties and Rebar Corrosion" (Doctoral thesis, University of Ghent, 2006).

14. N. Berke, T.G. Weil, "Worldwide Review of Corrosion Inhibitors in Concrete," in Advances in Concrete Technology, ed. V.M. Malhotra (Ottawa, Canada: CANMET, 1992), p. 899-924.

15. B. El-Jazairi, N.S. Berke, The Use of Calcium Nitrites as Cortosion Inhibiting Admixture to Steel Reinforcement in Concrete (Wishaw, Warwickshire, U.K.: Elsevier Science Publishers, Ltd., 1992)

16. C. Andrade, C. Alonso, J.A. Gonzälez, Cem Concr. Aggr. (1986) p. 110-116.

17. N.S. Berke, M.C. Hicks, Cem Concr. Compos. 26 (2004): p. 191-198.

18. A. Welle, J.D. Liao, K. Kaiser, M. Grunze, U. Mader, N. Blank, AppL Surf. ScL (1997): p. 185-190.

19. P. Martin, B.A. Milssic, "Corrosion Inhibiting in Reinforced Cement," Canadian Patent no. 1258473 (August 1989)

20. O.S.B. Al-Amoudei, M. Maslehuddin, A.N. Lashari, A.A. Almusallam, Cem. Concr. Compos. 25 (2003): p. 439-449

21. S. Feliú, J.A. Gonzälez, V. Feliū, L. Escudero, V. Ausin, C. Andrade, I.A. Rodriguez-Maribona, J.A. Bolano, F. Jiménez, "Corrosion Detecting Probes for Use with a Corrosion-Rate-Meter for Electrochemically Determining the Corrosion Rate of Reinforced Concrete Structures," invention patents CA2042883-A. ES2024268-A, US5259944-A, publication no. 5, 259,944-1993.

22. S. Feliú, J.A. Gonzālez, C. Andrade, J. Appl. Electrochem 26 (1996): p. 305-309.

23. C. Andrade, C. Alonso, J.A. González, "An Initial Effort to Use the Corrosion Rate Measurement for Estimating Rebar Durability," Corrosion Rates of Steel in Concrete," ASTM STP 1065, eds. N.S. Berke, V. Chaker, Whiting (West Conshohocken, PA: ASTM International, 1990), p. 29-37.

24. T.C. Rilem, Mater Struct. 37, 11 (2004): p. 623-643.

25. ASTM C276-91, "Standard Test Method for Half-Cell Potentials of Uncoated Reinforcing Steel in Concrete" (West Conshohocken. PA: ASTM International, 1991).

26. C. Andrade, C. Alonso, Constr. Build Mater. 15, 2-3 (2001): p. 141-145

27. J. Newman, J. Electrochem. Soc. 107 (1966): p. 501-502.

28. S. Feliü, C. Andrade, J.A. Gonzälez, C. Alonso, Mater. Struct. 29. 7 (1996): p. 362-365

29. R. Baessler, A. Burkert, "Laboratory Testing of Portable Equipment," Brite/Euram Project Integrated Monitoring System for Durability Assessment of Concrete Structures (Berlin, Germany: Federal Institute for Materials and Testing, 2001)

30. O.K. Gepraegs, C.M. Hansson, "A Comparative Evaluation of Three Commercial Instruments for Field Measurements of Reinforcing Steel Corrosion Rates," in Electrochemical Techriques for Evaluating Corrosion Performance and Estimating Service-Life of Reinforced Concrete (West Conshohocken, PA: ASTM International, 2004).

31. A. Poursaee, C.M. Hansson, Corros. Sci. 50, 10 [2008): p. 2,7392746 .

32. I. Martinez, "Advanced Electrochemical Techniques for On-Site Reinforcement Corrosion Measurement" (Doctoral thesis, Universidad Complutense de Madrid, 2003). 

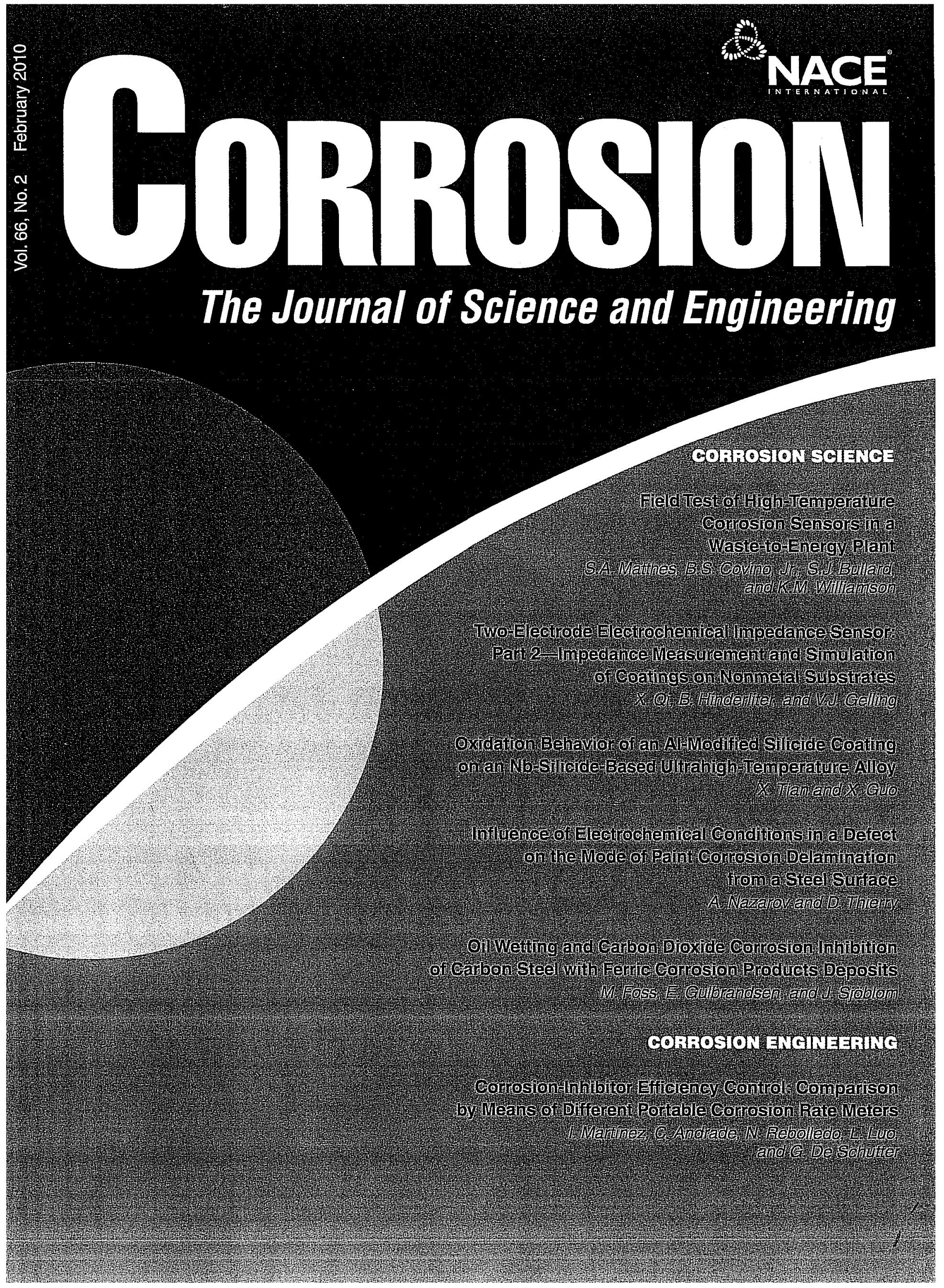